\title{
Visual examinations and soil physical and hydraulic properties for assessing soil structural quality of soils with contrasting textures and land uses
}

\author{
Mansonia Pulido Moncada a,b,*, Letiane Helwig Penning ${ }^{c}$, Luis Carlos Timm ${ }^{\mathrm{d}}$, \\ Donald Gabriels ${ }^{\mathrm{b}}$, Wim M. Cornelis ${ }^{\mathrm{b}}$ \\ ${ }^{a}$ Instituto de Edafología, Facultad de Agronomía, Universidad Central de Venezuela, Venezuela \\ ${ }^{\mathrm{b}}$ Department of Soil Management, UNESCO Chair on Eremology, Ghent University, Belgium \\ ${ }^{\mathrm{c}}$ Soil and Water Management and Conservation Postgraduate Programme, Faculty of Agronomy, Federal University of Pelotas, Pelotas, RS, Brazil \\ ${ }^{\mathrm{d}}$ Rural Engineering Department, Faculty of Agronomy, Federal University of Pelotas, Pelotas, RS, Brazil
}

\section{A R T I C L E I N F O}

\section{Article history:}

Received 12 November 2013

Received in revised form 27 January 2014

Accepted 11 February 2014

\section{Keywords:}

Visual soil evaluation

Type of aggregates

Soil hydraulic conductivity

Aggregate stability

\begin{abstract}
A B S T R A C T
This study evaluates the use and the ability of visual examinations for assessing soil structural quality (SSQ) in soils with contrasting textures and under different land uses. The study searched for similarities in SSQ class between visual examinations and soil physical and hydraulic properties (soil organic carbon (SOC), aggregate stability, bulk density, porosity, plant available water capacity (PAWC) and unsaturated and saturated hydraulic conductivity), as well as the statistical relationships between them. The visual examinations used were the visual evaluation of soil structure (VESS), the visual soil assessment (VSA), the visual assessment of aggregate stability and the visual type of aggregates index. The latter is proposed as a new visual index for assessing SSQ. Samples were taken on a sandy loam and a silt loam soil, both under cereal monoculture (CM) and permanent pasture (PP), with conventional tillage and no tillage, respectively. Visual examination methods indicated significant differences between $\mathrm{CM}$ and PP in the silt loam soil $(0.01<P<0.05)$, which were confirmed by significant differences in soil porosity and PAWC values. Wet sieving and the visual type of aggregates index were similar in identifying differences between land uses in both soils. Measurements of the visual type of aggregates index and of the hydraulic conductivity at different pressure heads were similar in indicating the soil structure condition of the soils. In the silt loam soil, the visual examinations were most related to properties such as SOC, PAWC, aggregate stability and porosity, whereas in the sandy loam soil they were most associated with water flow properties. The present study demonstrated that visual examinations are reliable semiquantitative methods to assess SSQ and could be considered as promising visual predictors of soil physical properties $\left(0.33<R^{2}<0.95\right)$. Finally, from the dissimilarities in terms of soil quality found with the VSA, VESS and porosity compare to the amount of SOC, SOC should be used cautiously as a sole indicator for soil structural quality as has been proposed in the literature, because SOC per se is not always well related to soil structural quality.
\end{abstract}

() 2014 Elsevier B.V. All rights reserved.

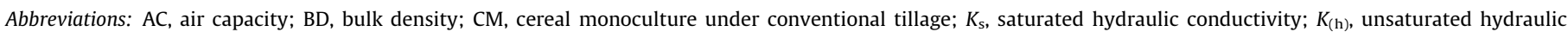

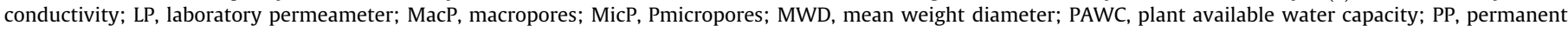

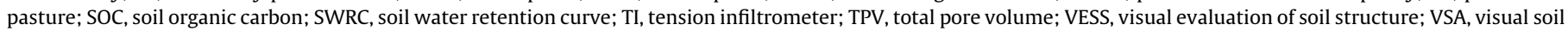
assessment.

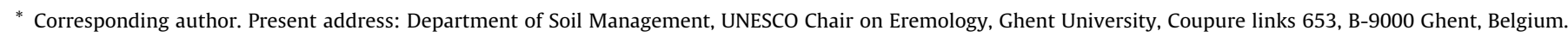
Tel.: +32 92646046; fax: +32 92646247.

E-mail addresses: mansoniapulido@gmail.com, pulidom@agr.ucv.ve, mansonia.pulido@UGent.be (M. Pulido Moncada).
} 


\section{Introduction}

In agricultural soils, tillage practices modify soil properties and quality and hence affect crop production and the environment (Batey and McKenzie, 2006). Machinery traffic, tillage and loss of soil organic matter have adverse effects on soil structural quality (Guimaraes et al., 2013) and are generally resulting in soil compaction (Batey, 2009). Loss of integrity of soil structural units, decrease in soil volume, increase in bulk density (BD), decrease in porosity and a reduction in saturated hydraulic conductivity $\left(K_{\mathrm{s}}\right)$ are the principal consequences of soil structure degradation and soil compaction (Newell-Price et al., 2013).

Soil structure is the property most frequently evaluated when determining soil quality under different land uses and tillage practices. Soil structure is usually evaluated in an indirect way from properties such as soil organic carbon (SOC) content, BD, porosity, soil water retention curve (SWRC), soil resistance to root growth, $K_{s}$, and infiltration rate (Lal and Shukla, 2004). These properties, which can be used as indicators of soil physical quality (Reynolds et al., 2009), are usually evaluated by classical tests, which refer in this paper to those laboratory and field measurements frequently used to characterize and monitor physical condition of soils. Despite the many instruments or techniques available to measure properties related to soil structure, there are many circumstances where such tests cannot be conducted or the number of samples has to increase to adequately capture the spatial and temporal variability (Batey, 2000).

Facing those limitations, the direct evaluation of morphological structural properties in the field is a possible alternative (Boizard et al., 2005). In recent years, several methods of visual field examination have been developed to provide a direct description of soil structure, helping farmers to take rapid decisions in order to improve the soil structural quality, and thus ensuring the soil's capacity of sustainable production. The importance of visual field examination of soil quality has been widely recognized as it plays a particularly important role in providing rapid semi-quantitative data on physical soil quality (Shepherd, 2000; Mueller et al., 2009; Garbout et al., 2013).

The morphological properties comprised in these methods are used in classical soil survey and classification. They are not competing with but rather complementary to soil physical properties measurements (Karlen et al., 2003). Morphological descriptions of soil structure also provide information that cannot easily be obtained by other methods, such as the shape and strength of aggregates, type of macropores, and macropores continuity and connectivity (Lin et al., 1999a). These are properties that reveal differences in quality between land use types and detect harvest compaction in cereal crops (Guimaraes et al., 2013).

Visual field examination methods are now being used in several countries and have shown value in explaining differences in crop performance and yield resulting from soil management and type (Ball et al., 2013). To provide similar information through other measures of soil physical condition such as BD, penetration resistance, porosity, water retention or hydraulic conductivity, requires several measurements and can be costly and time consuming (Newell-Price et al., 2013). Therefore, to encourage researchers and farmers to use simple but accurate indicators for evaluating and monitoring the soil structural quality and soil degradation, there is a need to extend the validation of simple visual examinations. In this survey, we seek for the applicability and validation of proposed visual examinations for soil structural quality assessment and the use of new visual indices such as the assessment of the type of aggregates.

Comparisons of visual examination of soils under different land uses and with contrasting textures, and their relationships with physical and hydraulic properties are not well documented in literature. The objective of this study is therefore to evaluate the use and the ability of visual field examinations for assessing soil structural quality in soils with contrasting textures and land uses by comparing them to soil physical and hydraulic properties related to function of the soil.

\section{Materials and methods}

\subsection{Field site description}

The survey was conducted in the Flanders Region of Belgium, on a sandy loam and a silt loam soil, textures commonly found in many agricultural soils in Belgium (Table 1). The sandy loam soil is a Cambisol located in the community of Kruishoutem $\left(50^{\circ} 59^{\prime} \mathrm{N}\right.$, $\left.3^{\circ} 31^{\prime} \mathrm{E}\right)$, where two plots of $810 \mathrm{~m}^{2}(18 \mathrm{~m} \times 45 \mathrm{~m})$ were selected, one under cereal mono-cropping (Zea mays L.) with conventional tillage (CM) and another under permanent pasture (PP). Conventional tillage consisted of primary tillage with mouldboard plough, and secondary tillage with harrow + seed drill. PP is used in this area to protect the soil surface against erosion and is free of grazing. The silt loam soil is a Luvisol located in the community of Heestert $\left(50^{\circ} 47^{\prime} \mathrm{N}, 3^{\circ} 24^{\prime} \mathrm{E}\right)$, where again two plots of $810 \mathrm{~m}^{2}$ $(18 \mathrm{~m} \times 45 \mathrm{~m})$ were selected: one under rotation of corn (Zea mays L.) and winter wheat (Triticum aestivum L.) with conventional tillage, and the other under PP with the constant presence of cattle (7.5 animals per ha). Here, conventional tillage comprised primary tillage with cultivator + mouldboard plough, followed by secondary tillage with harrow and seed drill.

\subsection{Soil sampling}

In each plot, six sampling points were randomly selected and soil cores were taken simultaneously with an on field morphological evaluation of soil structure. Three soil samples were taken with $\sim 100 \mathrm{~cm}^{3}$ Kopecky steel rings (inner diameter of $5.1 \mathrm{~cm}$ and a height of $5 \mathrm{~cm})$ at the half way of the top soil layer $(0-10 \mathrm{~cm})$ in each sampling point to determine BD, SWRC and $K_{\mathrm{s}}$, hence three replicates per point per property. Two undisturbed blocks of soil

Table 1

Description and characteristics of a sandy loam and a silt loam soil under cereal monoculture (CM) and permanent pasture (PP).

\begin{tabular}{|c|c|c|c|c|c|c|c|c|c|c|c|c|c|}
\hline Soils & $\begin{array}{l}\text { Land } \\
\text { use }\end{array}$ & WRB class & Drainage status & $\begin{array}{l}\text { Clay } \\
\left(\mathrm{g} \mathrm{kg}^{-1}\right)\end{array}$ & $\begin{array}{l}\text { Silt } \\
\left(\mathrm{g} \mathrm{kg}^{-1}\right)\end{array}$ & $\begin{array}{l}\text { VFS } \\
\left(\mathrm{g} \mathrm{kg}^{-1}\right)\end{array}$ & $\begin{array}{l}\text { FS } \\
\left(\mathrm{g} \mathrm{kg}^{-1}\right)\end{array}$ & $\begin{array}{l}\text { MS } \\
\left(\mathrm{g} \mathrm{kg}^{-1}\right)\end{array}$ & $\begin{array}{l}\mathrm{CS} \\
\left(\mathrm{g} \mathrm{kg}^{-1}\right)\end{array}$ & $\begin{array}{l}\text { VCS } \\
\left(\mathrm{g} \mathrm{kg}^{-1}\right)\end{array}$ & $\begin{array}{l}\text { SOM } \\
\left(\mathrm{g} \mathrm{kg}^{-1}\right)\end{array}$ & $\mathrm{pH}_{\mathrm{KCl}}$ & $\begin{array}{l}\text { EC } \\
\left(\mathrm{dS} \mathrm{m} \mathrm{m}^{-1}\right)\end{array}$ \\
\hline \multirow{2}{*}{ Sandy loam } & $\mathrm{CM}$ & Cambisol & Well drained & 136 & 120 & 426 & 272 & 38 & 6 & 2 & 23.2 & 5.96 & 0.10 \\
\hline & PP & Cambisol & Well drained & 102 & 155 & 379 & 307 & 39 & 11 & 7 & 26.8 & 4.60 & - \\
\hline \multirow[t]{2}{*}{ Silt loam } & $\mathrm{CM}$ & Luvisol & $\begin{array}{l}\text { Moderately } \\
\text { well drained }\end{array}$ & 125 & 657 & 128 & 74 & 13 & 2 & 1 & 18.9 & 6.22 & 0.18 \\
\hline & PP & Luvisol & $\begin{array}{l}\text { Moderately } \\
\text { well drained }\end{array}$ & 142 & 646 & 113 & 82 & 12 & 3 & 2 & 55.6 & 5.58 & - \\
\hline
\end{tabular}

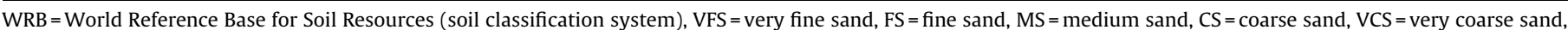
$\mathrm{SOM}=$ soil organic matter.

$\mathrm{pH}$ and EC (soil electrical conductivity) were determined in 1:2.5 soil solution ratio. 
$(20 \mathrm{~cm} \times 10 \mathrm{~cm} \times 20 \mathrm{~cm})$ were extracted from each sampling point to conduct the visual field examination. The water content at sampling was close to field capacity $(-33 \mathrm{kPa})$.

\subsection{Soil physical and hydraulic properties for assessing the soil structural quality}

The soil physical properties evaluated were aggregate stability, $\mathrm{BD}$, porosity, plant available water capacity (PAWC) and unsaturated and saturated hydraulic conductivity. Also, particle size distribution by sedimentation using the pipette method (Gee and Or, 2002), SOC by wet oxidation (Walkley and Black, 1934), gravimetric soil water content, $\mathrm{pH}$ and EC (soil electrical conductivity) were determined.

\subsection{1. $B D$, porosity and PAWC}

The SWRC was constructed by measuring soil water content at eight matric potentials. For the matric potential ranging from -0.1 to $-10 \mathrm{kPa}$, the sand box apparatus (Eijkelkamp Agrisearch Equipment, the Netherlands) was used. Pressure chambers were used to measure the water content at matric potential of $-33 \mathrm{kPa}$, $-100 \mathrm{kPa}$ and $-1500 \mathrm{kPa}$ (Soilmoisture Equipment, Santa Barbara, CA, USA). The procedure is described by Cornelis et al. (2005). Soil $\mathrm{BD}$ was determined at $-10 \mathrm{kPa}$ matric potential. Total pore volume (TPV), macroporosity (MacP, $\theta_{\mathrm{h}=0 \mathrm{kPa}}-\theta_{\mathrm{h}=-1 \mathrm{kPa}}$ ), microporosity (MicP, $\left.\theta_{\mathrm{h}=0 \mathrm{kPa}}-\left[\theta_{\mathrm{h}=0 \mathrm{kPa}}-\theta_{\mathrm{h}=-10 \mathrm{kPa}}\right]\right)$, air capacity $\left(A C, \theta_{\mathrm{h}=0 \mathrm{k}-}\right.$ $\left.\mathrm{Pa}-\theta_{\mathrm{h}=-10 \mathrm{kPa}}\right)$, and PAWC $\left(\theta_{\mathrm{h}=-33 \mathrm{kPa}}-\theta_{\mathrm{h}=-1500 \mathrm{kPa}}\right)$ were calculated from the SWRC data, with h denoting matric potential.

\subsubsection{Soil hydraulic conductivity}

$K_{\mathrm{s}}$ was obtained by using two methods: (i) on soil cores with the constant-head method (Klute and Dirksen, 1986), using a laboratory permeameter (LP), and (ii) in the field with a tension infiltrometer (TI), similar to that described by Reynolds and Elrick (1991). Geometric means of the three values per sampling point were taken.

In case of LP the undisturbed core samples were placed in a closed permeameter (Eijkelkamp Agrisearch Equipment) after saturation. A constant water head was obtained by creating a difference in water pressure on both sides of the saturated soil sample so that a water flow was passing through the soil sample. The flow was measured until a constant water flux was observed and $K_{\mathrm{s}}$ was then determined using Darcy's equation.

$K_{\mathrm{s}}=\frac{Q L}{A d}$

where $Q$ is the outflow through the soil core $\left(\mathrm{cm}^{3} \mathrm{~h}^{-1}\right), L$ is the length of the soil core $(\mathrm{cm}), A$ is the surface area of the soil core $\left(\mathrm{cm}^{2}\right)$, and $d$ is the applied hydraulic head $\left(\mathrm{cmH}_{2} \mathrm{O}\right)$.

The TI method (Soilmoisture Equipment) was applied in a relatively levelled spot where local surface irregularities were covered with a fine layer of $\sim 5 \mathrm{~mm}$ of sand $(0.5-0.10 \mathrm{~mm}$ in diameter) to ensure a good hydraulic contact between the disc and the soil surface. Apparent steady-state infiltration rates were measured at sequential supply water potentials of $-10,-6,-3$ and $-1 \mathrm{cmH}_{2} \mathrm{O}$. It was assumed, based on the capillary theory, that these water potentials exclude pores of diameter or fissures of width greater than $0.30 \mathrm{~mm}, 0.5 \mathrm{~mm}, 1 \mathrm{~mm}$, and $3 \mathrm{~mm}$, respectively from participating in the water flow.

The non-linear regression method (Logsdon and Jaynes, 1993) based on the theoretical analysis of the steady-state water flux under the infiltrometer (Wooding, 1968) was used to calculate soil $K_{(\mathrm{h})}$ and $\alpha$ according to:

$\frac{Q x(h)}{\pi R^{2}}=K_{\mathrm{s}} \exp (\alpha h)+\frac{\left[4 K_{\mathrm{s}} \exp (\alpha h)\right]}{\pi R \alpha}$ where $Q x(h)$ is the steady infiltration rate under pressure head of $h$ $(-\mathrm{m}), R$ is the radius of the disc, and $\alpha$ is the Gardner constant which characterizes the soil pore size distribution. The parameter $K_{\mathrm{s}}$ and $\alpha$ were determined by curve-fitting, using the LevenbergMarquardt algorithm, allowing to determine hydraulic conductivity $K_{(\mathrm{h})}$ under any other pressure head $h$ from Gardner's exponential function:

$K_{(\mathrm{h})}=K_{\mathrm{s}} \exp (\alpha h)$

\subsection{Morphological characterization of field soil structure}

The morphological characterization of soil structure was conducted by using two methods of visual field examination: visual evaluation of soil structure (VESS) by Ball et al. (2007) based on Peerlkamp (1959) and modified by Guimaraes et al. (2011), and visual soil assessment (VSA) by Shepherd (2009). For this visual field examination, two blocks of soil $(20 \mathrm{~cm}$ deep, $10 \mathrm{~cm}$ thick and $20 \mathrm{~cm}$ long) were taken at each sampling location. One block was broken by hand (VESS) and the other by dropping one to three times from a height of $1 \mathrm{~m}$ into a plastic tray (VSA).

\subsubsection{Visual evaluation of soil structure (VESS)}

The evaluation of the soil blocks was conducted according to the methodology described by Ball et al. (2007). This consists of identifying layers of contrasting structure and giving a score to each soil layer by comparing the appearance of the soil block (after hand breaking) with a visual key proposed by Guimaraes et al. (2011). The overall score of a soil is then determined by multiplying the score of each layer by its thickness and dividing the product by the overall depth. The blocks of soil were graded on a scale from 1 to 5 where 1 represents the best condition. Scores were fitted between structural quality categories when the soil block had the properties of both. The assigned score was based on factors such as difficulty in extracting the soil block, aggregate type and size, presence of large worm holes, root clustering, thickness and deflections, and the necessity to break large aggregates to small fragments to reveal their type. Soils with scores of 1-3 have an 'acceptable' condition of soil structure, whereas those with scores of 4-5 have a 'limiting' condition and require management practice changes.

\subsubsection{Visual soil assessment (VSA)}

The VSA was conducted as described by Shepherd (2009). Each indicator used by this method (soil texture, soil structure, soil porosity, number and colour of soil mottles, soil colour, earthworms, soil smell, potential rooting depth, surface ponding, surface cover and surface crusting, and soil erosion), was given a visual score of 0 (poor), 1 (moderate), 2 (good), or an in-between score $(0.5=$ moderately poor and $1.5=$ moderately good $)$. This scoring was done by comparing the soil with the description of each indicator and the photographs from the VSA field guide manual. The ratings for each indicator were then weighted and summed resulting in a final score for the soil structural quality. The field guide manual for cropping land was used in CM, whereas in the other plots (PP) the manual for pastoral grazing was applied. Soils with a sum of visual scores $<20$ (under both grazing and cropping) have a poor soil quality, and soils with values $>35$ (under grazing) or $>37$ (under cropping) have a good soil quality. Values in between those ranges have a moderate soil quality condition.

\subsection{Visual soil structural quality assessment based on type of aggregates}

The type of aggregates, in terms of form, was considered as an individual morphological index of soil structural quality, namely visual type of aggregates index. After hand breaking of the soil for 
Table 2

Criteria used to score the type of aggregate and soil structural quality.

\begin{tabular}{llll}
\hline Type of aggregate & Abundance & Score & $\begin{array}{l}\text { Soil structural } \\
\text { quality class }\end{array}$ \\
\hline Rounded and crumbly & $100 \%$ round & 1 & Good \\
Sub angular blocky & $100 \%$ sub angular & 2 & Moderately good \\
Sub angular and angular blocky & $>50 \%$ sub angular & 3 & Moderate \\
Angular and sub angular blocky & $>50 \%$ angular & 4 & Moderately poor \\
Angular blocky & $100 \%$ angular & 5 & Poor \\
\hline
\end{tabular}

the visual soil evaluation, aggregates of $1-2 \mathrm{~cm}$ in diameter were described in terms of shape according to FAO (2006). The abundance of rounded aggregates was considered as an indicator of 'good' quality for crop growth, and the abundance of sharper edge aggregates as 'poor' quality. The abundance of a certain type of aggregates was graded on a scale from 1 to 5 , where 1 was the best (Table 2). This scale was based on the appearance of small aggregates as is considered in the key of VESS described by Guimaraes et al. (2011).

\subsection{Visual soil structural quality assessment based on water aggregate stability}

Soil structural quality was also assessed by evaluating the water aggregate stability. Two methods were used: wet sieving, and visual evaluation of the degree of fragmentation and dispersion of aggregates. The wet sieving test was conducted using the Yoder method modified by Kemper and Rosenau (1986). Air-dried aggregates of 1-2 $\mathrm{mm}$ in diameter were sieved on a single sieve $(0.25 \mathrm{~mm})$ in distilled water for 3 minutes at a constant, automatically controlled speed. The mean weight diameter (MWD) was calculated from the water stable aggregates:

$\mathrm{MWD}=\frac{W_{\mathrm{s}} d}{W_{\mathrm{t}}}$

where $W_{\mathrm{s}}$ is the stable soil aggregate fraction $(\mathrm{g}), d$ is the mean diameter of the fraction $(\mathrm{mm})$, and $W_{\mathrm{t}}$ is the total weight of the sample ( $\mathrm{g}$ ).

The visual assessment of the aggregate stability was conducted by visually evaluating the ability of the aggregate in maintaining its initial shape and size after immersion in water. The modified Emerson test described by Field et al. (1997) was used as reference. Per sampling point, 12 aggregates of $1-2 \mathrm{~cm}$ in diameter were placed in a ceramic plate with separated cavities. Each cavity was filled with distilled water so that the aggregates were completely immersed. Visual assessment of the degree of fragmentation and dispersion was made 5 and $10 \mathrm{~min}$ after immersion of the aggregates. This measurement was done either on aggregates at sampling water content, near field capacity ( $-33 \mathrm{kPa}$ matric potential), and airdried.

A visual appraisal of the aggregates appearance was made according to the graphical scheme of aggregate stability test of Beste (1999). An overall score between 0 and 2 was assigned. A score of 2 indicates no or slight fragmentation and dispersion, 1 indicates fragmentation in more than two fragments and moderate dispersion; and a score of 0 indicates strong dispersion and muddy water. Scores were individually given to each aggregate, and an average score was given afterwards for each sample.

\subsection{Statistical analyses}

In this survey a strip design (with six measurements taken randomly within strip) was conducted instead of a complete randomized block design. This was based on the spatial homogeneity of soil texture present on each study area (Saey et al., 2008). As spatial variability was taken into account, part of the variability determined by a randomized block design was also accounted for (Fagroud and Van Meirvenne, 2002). ANOVA was used as a tool to discuss significant differences in soil structural quality indicators. However, significant differences found have to be seen within the limitations of the experimental design and therefore are rather considered as tendencies. Nonparametric Kruskal-Wallis rank sum tests were conducted to detect statistical differences among land use in both soils for each measured variable. Further, Spearman correlation tests were conducted to measure the association between each pair of variables. A Levene's test (Schultz, 1985) was applied to compare the variability in the scores between the different methods (VESS and VSA). The Levene's test was conducted by performing an analysis of variance on the coefficients of variation (C.V.) with methods as a factor, and on the ratio of the absolute deviations associated with each observation from its respective group mean divided by the group mean. All tests were conducted at the $5 \%$ significance level. With the aim of assessing the tendency of the relationships between soil physical indicators and the visual examination of soil structural quality for both soils, analyses of simple regression was performed. All analyses were performed using the statistical package SPSS 17.0.

\section{Results}

\subsection{Comparison of soil structural quality evaluated by visual field examinations and by soil physical properties}

In the sandy loam soil, the difference in scores of the visual field examination methods, VSA and VESS, was statistically not significant $(P>0.05)$ under CM and PP. Both VSA and VESS

\section{Table 3}

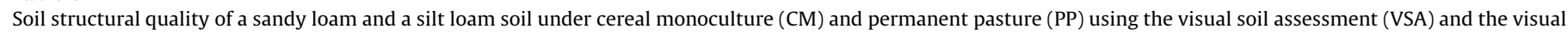
evaluation of soil structure (VESS). With VSA, lower values refer to poorer soil quality, whereas with VESS lower values indicate better soil structural quality.

\begin{tabular}{|c|c|c|c|c|c|c|c|c|c|}
\hline \multirow[t]{3}{*}{ Soils } & \multirow[t]{3}{*}{ Land use } & \multicolumn{6}{|c|}{ VSA } & \multirow{2}{*}{\multicolumn{2}{|c|}{ VESS }} \\
\hline & & \multicolumn{2}{|c|}{ Soil structure } & \multicolumn{2}{|c|}{ Soil porosity } & \multicolumn{2}{|c|}{ Soil quality } & & \\
\hline & & Score & Class & Score & Class & Score & Class & Score & Class \\
\hline \multirow[t]{2}{*}{ Sandy loam } & $\mathrm{CM}$ & $\begin{array}{l}1.5 \mathrm{a} \\
(0.3)\end{array}$ & Good & $\begin{array}{l}1.1 \mathrm{a} \\
(0.2)\end{array}$ & Moderate & $\begin{array}{l}31 \mathrm{a} \\
(2.9)\end{array}$ & Moderate & $\begin{array}{l}3.0 \mathrm{a} \\
(0.8)\end{array}$ & Moderate \\
\hline & $\mathrm{PP}$ & $\begin{array}{l}1.7 \mathrm{a} \\
(0.4)\end{array}$ & Good & $\begin{array}{l}1.0 \mathrm{a} \\
(0.0)\end{array}$ & Moderate & $\begin{array}{l}32 \mathrm{a} \\
(1.4)\end{array}$ & Moderate & $\begin{array}{l}2.8 \mathrm{a} \\
(0.5)\end{array}$ & Moderate \\
\hline \multirow[t]{2}{*}{ Silt loam } & $\mathrm{CM}$ & $\begin{array}{l}1.4 \mathrm{a} \\
(0.2)\end{array}$ & Moderate & $\begin{array}{l}1.2 \mathrm{a} \\
(0.2)\end{array}$ & Moderate & $\begin{array}{l}35 \mathrm{a} \\
(2.7)\end{array}$ & Moderate & $\begin{array}{l}2.7 \mathrm{a} \\
(0.3)\end{array}$ & Moderate \\
\hline & PP & $\begin{array}{l}1.1 \mathrm{a} \\
(0.3)\end{array}$ & Moderate & $\begin{array}{l}1.0 \mathrm{a} \\
(0.0)\end{array}$ & Moderate & $\begin{array}{l}31 \mathrm{~b} \\
(1.6)\end{array}$ & Moderate & $\begin{array}{l}3.4 \mathrm{~b} \\
(0.1)\end{array}$ & Poor \\
\hline
\end{tabular}

Standard deviation for each index is given in parenthesis $( \pm)$.

Values in a column followed by the same letter are not significantly different at $P>0.05$. 
Table 4

Soil properties of a sandy loam and a silt loam soil under cereal monoculture (CM) and permanent pasture (PP).

\begin{tabular}{|c|c|c|c|c|c|c|c|c|c|c|}
\hline Soil & $\begin{array}{l}\text { Land } \\
\text { use }\end{array}$ & $\begin{array}{l}\mathrm{SOC} \\
\left(\mathrm{g} \mathrm{kg}^{-1}\right)\end{array}$ & $\begin{array}{l}\mathrm{BD} \\
\left(\mathrm{Mg} \mathrm{m}^{-3}\right)\end{array}$ & $\begin{array}{l}\text { TPV } \\
\left(\mathrm{cm}^{3} \mathrm{~cm}^{-3}\right)\end{array}$ & $\begin{array}{l}\text { MacP } \\
\left(\mathrm{cm}^{3} \mathrm{~cm}^{-3}\right)\end{array}$ & $\begin{array}{l}\text { MicP } \\
\left(\mathrm{cm}^{3} \mathrm{~cm}^{-3}\right)\end{array}$ & $\begin{array}{l}\mathrm{AC} \\
\left(\mathrm{cm}^{3} \mathrm{~cm}^{-3}\right)\end{array}$ & $\begin{array}{l}\mathrm{FC} \\
\left(\mathrm{cm}^{3} \mathrm{~cm}^{-3}\right)\end{array}$ & $\begin{array}{l}\text { PWP } \\
\left(\mathrm{cm}^{3} \mathrm{~cm}^{-3}\right)\end{array}$ & $\begin{array}{l}\text { PAWC } \\
\left(\mathrm{cm}^{3} \mathrm{~cm}^{-3}\right)\end{array}$ \\
\hline \multirow[t]{2}{*}{ Sandy loam } & $\mathrm{CM}$ & $\begin{array}{l}11.6 \mathrm{~b} \\
(1.5)\end{array}$ & $\begin{array}{l}1.29 \mathrm{a} \\
(0.07)\end{array}$ & $\begin{array}{l}0.51 \mathrm{a} \\
(0.03)\end{array}$ & $\begin{array}{l}0.05 \mathrm{a} \\
(0.01)\end{array}$ & $\begin{array}{l}0.36 \mathrm{~b} \\
(0.02)\end{array}$ & $\begin{array}{l}0.16 \mathrm{a} \\
(0.01)\end{array}$ & $\begin{array}{l}0.20 \\
(0.01)\end{array}$ & $\begin{array}{l}0.02 \\
(0.01)\end{array}$ & $\begin{array}{l}0.18 \mathrm{a} \\
(0.01)\end{array}$ \\
\hline & PP & $\begin{array}{l}13.4 \mathrm{a} \\
(1.1)\end{array}$ & $\begin{array}{l}1.31 \mathrm{a} \\
(0.03)\end{array}$ & $\begin{array}{l}0.51 \mathrm{a} \\
(0.01)\end{array}$ & $\begin{array}{l}0.04 \mathrm{a} \\
(0.02)\end{array}$ & $\begin{array}{l}0.39 a \\
(0.02)\end{array}$ & $\begin{array}{l}0.12 \mathrm{~b} \\
(0.01)\end{array}$ & $\begin{array}{l}0.28 \\
(0.01)\end{array}$ & $\begin{array}{l}0.08 \\
(0.02)\end{array}$ & $\begin{array}{l}0.20 \mathrm{a} \\
(0.02)\end{array}$ \\
\hline \multirow[t]{2}{*}{ Silt loam } & $\mathrm{CM}$ & $\begin{array}{l}9.4 \mathrm{~b} \\
(0.5)\end{array}$ & $\begin{array}{l}1.34 \mathrm{a} \\
(0.09)\end{array}$ & $\begin{array}{l}0.50 \mathrm{~b} \\
(0.03)\end{array}$ & $\begin{array}{l}0.10 \mathrm{a} \\
(0.04)\end{array}$ & $\begin{array}{l}0.32 \mathrm{~b} \\
(0.02)\end{array}$ & $\begin{array}{l}0.17 \mathrm{a} \\
(0.05)\end{array}$ & $\begin{array}{l}0.26 \\
(0.02)\end{array}$ & $\begin{array}{l}0.11 \\
(0.02)\end{array}$ & $\begin{array}{l}0.15 \mathrm{~b} \\
(0.02)\end{array}$ \\
\hline & PP & $\begin{array}{l}27.8 \mathrm{a} \\
(4.1)\end{array}$ & $\begin{array}{l}1.25 \mathrm{a} \\
(0.04)\end{array}$ & $\begin{array}{l}0.55 a \\
(0.02)\end{array}$ & $\begin{array}{l}0.02 \mathrm{~b} \\
(0.01)\end{array}$ & $\begin{array}{l}0.51 \mathrm{a} \\
(0.01)\end{array}$ & $\begin{array}{l}0.04 \mathrm{~b} \\
(0.01)\end{array}$ & $\begin{array}{l}0.45 \\
(0.02)\end{array}$ & $\begin{array}{l}0.15 \\
(0.03)\end{array}$ & $\begin{array}{l}0.31 \mathrm{a} \\
(0.04)\end{array}$ \\
\hline
\end{tabular}

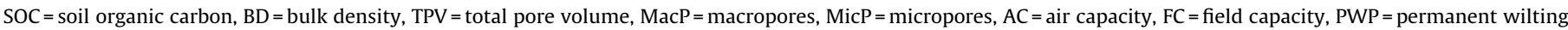
point, PAWC = permanent available water capacity.

Standard deviation for each soil property is given in parenthesis $( \pm)$.

Values in a column followed by the same letter are not significantly different at $P>0.05$ between land uses.

methods indicated 'moderate' soil structural quality for crop growth and root penetration under both land uses (Table 3 ). Regarding the silt loam soil, both VSA and VESS were able to distinguish a poorer condition in terms of soil quality for the PP plot under permanent grazing. Significant differences were found between land uses for VSA and VESS scores $(0.01<P<0.05)$.

In the sandy loam soil, VESS revealed a higher variability (21.3\%) than VSA $(5.5 \%)(P<0.01)$. In the silt loam soil, differences in C.V. (VESS $=17.2 \%$, VSA $=8.7 \%)$ were not found $(P>0.05)$. This suggests that in sandy soils, VSA is less sensitive for revealing slight spatial variation, in contrast with the silt loam soil for which both methods showed a response to differences in soil quality condition. Conversely, Spearman correlations indicated high and significant correlations between both methods $(r=-0.83)$.

Results from VSA and VESS methods were compared to soil physical properties results (Table 4 ) in terms of soil quality class. Soil BD did not reflect the differences in soil quality $(P>0.05)$, among soils and land uses, shown by the visual field examination methods. BD values were lower than $1.63 \mathrm{Mg} \mathrm{m}^{-3}$ and $1.49 \mathrm{Mg} \mathrm{m}^{-3}$, which are according to Pierce et al. (1983), critical values for adequate aeration and unlimited root elongation for sandy loam and silt loam, respectively.

When SOC was considered for comparison, the PP plot with silt loam soil was having a 'good' soil quality and the rest are classified as 'poor'. A value of $23 \mathrm{~g} \mathrm{~kg}^{-1}$ of SOC is considered the lower critical limit for maintaining a good soil structure in tilled soil (Greenland, $1981)$. The SOC values were higher in PP than $\mathrm{CM}(0.01<P<0.05)$ in both soils, which indicates better soil quality. This is distinct with respect to the soil quality of the visual examination results (VSA and VESS).

Regarding the individual score for the most critical indicators of VSA method, i.e., soil structure and soil porosity, the best soil structure condition (higher score) was found in the sandy loam soil. Differences in visual structure and porosity conditions were not found among land uses under the different soils (Table 3 ). However, the lowest scores for soil structure and porosity were found in the PP with permanent grazing in the silt loam soil, which is in correspondence with the values of the soil porosity indicators. In this plot, values of MacP, MicP and AC (Table 4) felt in a 'poor' soil quality class based on the threshold value proposed by Reynolds et al. (2007). In contrast, in both soils and land uses the PAWC values were $>0.10 \mathrm{~m}^{3} \mathrm{~m}^{-3}$, which can be considered as a 'good' quality for maximum root growth and adequate to store and provide water to plant roots (Reynolds et al., 2007).

\subsection{Comparison of soil structural quality evaluated by visual type of aggregates index and by water flow}

The abundance of a certain type of aggregates was tested as a new index of soil structural quality for our soils (Table 5). Subangular blocky aggregates were abundant in the sandy loam soil, but in 5 out of the 12 soil blocks evaluated aggregates with sharper edges and a firmer consistence were present in the second layer $(5-20 \mathrm{~cm}$ ) of the $20 \mathrm{~cm}$ soil blocks. The overall visual type of aggregates index score given to this soil, corresponded to a 'moderate' soil structural quality condition and no differences were found between land uses $(P>0.05)$.

Most aggregates present in the silt loam soil were subangular blocky in shape, for both CM and PP land uses $(P>0.05)$, which correspond to a 'moderately good' soil quality. No-angular aggregates were found in the PP plot under permanent grazing in this soil, meaning that the visual type of aggregates index does not reveal the poorer condition described by the previous indicators in this plot.

The soil quality classes based on the visual type of aggregates index were compared to the water flow measurements. Despite not finding any significant differences in $K_{\mathrm{s}}(P>0.05)$ between the land uses for both LP and TI measurements at the two sites (Fig. 1), measurements in the sandy loam soil with LP displayed 'moderate' and 'moderately slow' permeability classes in CM and $\mathrm{PP}$, respectively (NRCS, 2003). In the silt loam soil, $K_{\mathrm{s}}$ values in CM and PP were classified as 'moderately rapid' and 'moderate' permeability, respectively. This demonstrates that the aggregates with sharper edges and a firmer consistence found in the sandy

Table 5

Soil structural quality based on the visual type of aggregates index of a sandy loam and a silt loam soil under cereal monoculture (CM) and permanent pasture (PP).

\begin{tabular}{|c|c|c|c|c|c|}
\hline Soils & Land use & $\theta\left(\mathrm{cm}^{3} \mathrm{~cm}^{-3}\right)$ & Aggregate form & Score & Class \\
\hline \multirow[t]{2}{*}{ Sandy loam } & $\mathrm{CM}$ & 0.21 & Subangular and angular blocky & $2.8(1.2) \mathrm{a}$ & Moderate \\
\hline & $\mathrm{PP}$ & 0.17 & Subangular and angular blocky & $2.8(1.1) \mathrm{a}$ & Moderate \\
\hline \multirow[t]{2}{*}{ Silt loam } & $\mathrm{CM}$ & 0.28 & Subangular blocky & $2.4(0.3) \mathrm{a}$ & Moderately good \\
\hline & $\mathrm{PP}$ & 0.30 & Subangular blocky & $2.3(0.5) \mathrm{a}$ & Moderately good \\
\hline
\end{tabular}

$\theta=$ volumetric soil water content at sampling.

Standard deviation of the mean value is given in parenthesis $( \pm)$.

Values in a column followed by the same letter are not significantly different at $P>0.05$. 

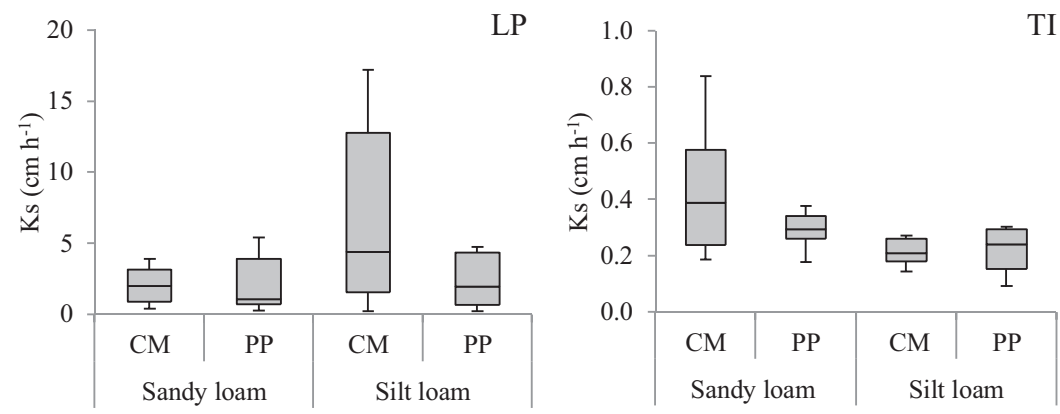

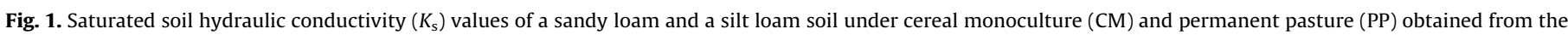

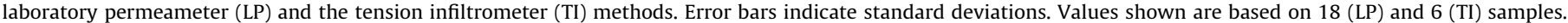

loam soil could restrict the water flow. Regarding the $K_{\mathrm{s}}$ values estimated from TI measurements, the NRCS permeability classification is not appropriate since it was based on vertical flow (ring samples) while in TI there is also lateral flow.

Fig. 2 shows, for both soil and land uses, a decreasing trend in $K_{(\mathrm{h})}$ from the pressure head at $-1 \mathrm{cmH}_{2} \mathrm{O}$ (corresponding with pores of $3 \mathrm{~mm}$ in diameter) to the pressure head at $-10 \mathrm{~cm} \mathrm{H}_{2} \mathrm{O}$ (representing a pore size of $0.3 \mathrm{~mm}$ in diameter). In the sandy loam soil, $K_{(\mathrm{h})}$ was higher for CM than for PP, whereas an opposite trend was observed in the silt loam soil. No significant differences were found between the land uses $(P>0.05)$, which correspond to the results from the visual type of aggregates index.

\subsection{Comparison of soil structural quality evaluated by water aggregate stability}

Aggregate stability was evaluated using the classical test of wet sieving and a visual examination method (Table 6). With regards to wet sieving, the reduction of MWD using fast wetting of air-dried aggregates of $1-2 \mathrm{~mm}$ in diameter was $>50 \%$ for $\mathrm{CM}$ and $<30 \%$ for PP for both soils. A stable soil was considered to have $>70 \%$ of the aggregates remaining on the sieve of $0.25 \mathrm{~mm}$ after wet sieving, and an unstable soil has $<50 \%$. The wet sieving test showed that there was an effect of the land uses on aggregate stability for both soils. Aggregates from PP were more resistant to breakdown after wet sieving when fast wetting was applied $(P<0.05)$.

Regarding the visual evaluation of aggregate stability, when field moist aggregates (approximately field capacity) were immersed in distilled water, no changes in type and size of aggregates were observed. However, when aggregates were airdried, fragmentation of the aggregates and dispersion of particles were observed for both soils under CM $(P<0.01)$. Consequently, when air-dried aggregates were used, the soil structural quality of the sandy loam and silt loam soils under CM was visually classified as 'moderate' and 'poor', respectively. These results reveal an effect of slaking, when the aggregates collapse because of entrapped air, resulting from poor pore arrangement and weak bonds. Conversely, PP for both soils resulted in 'good' soil structural quality by this measure, irrespective of the antecedent moisture status of the samples. Like the wet sieving test, the visual evaluation of aggregate stability was able to distinguish differences in soil structural quality between land uses in both soils.

\subsection{Relationships between morphological scores and values of soil physical and hydraulic properties}

Besides searching for the similarities found between the morphological evaluations and the soil physical and hydraulic properties in classifying the soil structural quality of the soil, we also sought statistical relationships between them. Table 7 shows those regression equations that were significant at $P=0.05$, with soil physical and hydraulic properties as dependent variable and the scores obtained from the various visual examination methods as independent variable. A relationship between VSA and BD was observed in sandy loam soil, with $R^{2}=0.50$. Relationships between VSA and SOC, MacP, MicP, AC, PAWC and MWD were observed in silt loam soil, with $R^{2}$ values ranging from 0.35 to 0.50 . VESS was also related to $\operatorname{SOC}\left(R^{2}=0.51\right)$, $\operatorname{MicP}\left(R^{2}=0.47\right)$, TPV $\left(R^{2}=0.47\right)$, PAWC $\left(R^{2}=0.35\right)$ and MWD $\left(R^{2}=0.47\right)$ in the silt loam soil. In the sandy loam soil, VESS was only related to $K_{(\mathrm{h})}$ at different pressure heads $\left(0,-1,-3\right.$ and $\left.-10 \mathrm{cmH}_{2} \mathrm{O}\right)$, with $R^{2}$ values ranging from 0.37 to 0.43 . The individual scores given for the soil structure and the soil porosity according to the VSA method were not correlated with any of the soil physical and hydraulic properties.

The visual type of aggregates index was only related to $K_{(\mathrm{h})}$ at different pressure heads in both soils. The strongest relationships were between the visual type of aggregates index and $K_{\mathrm{s}}$ estimated from TI measurements $\left(R^{2}=0.40\right)$ in the sandy soil, and with $K_{(\mathrm{h})}$ at
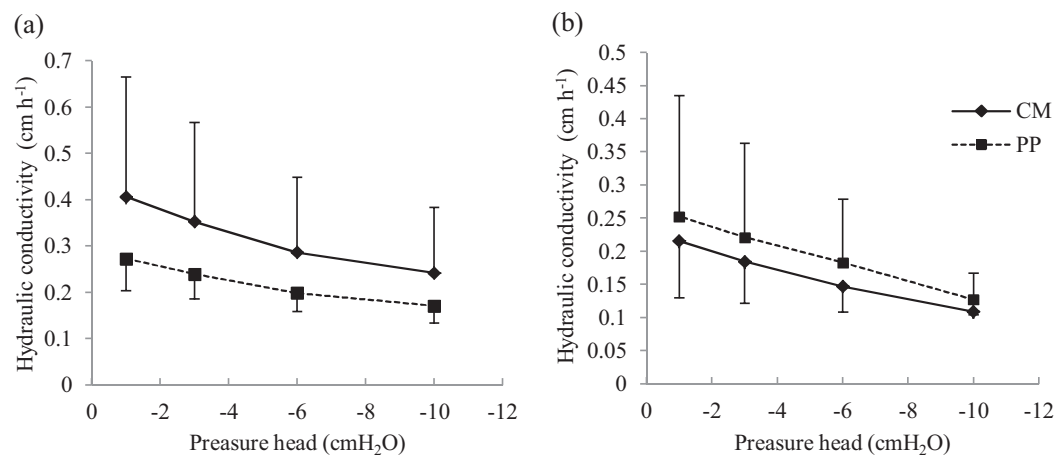

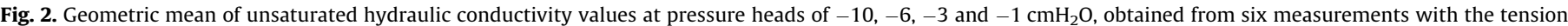

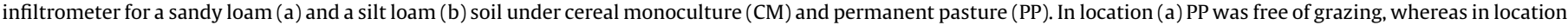
(b) was under permanent cattle grazing. Error bars indicate standard deviations. No significant differences between land uses were found $(P>0.05)$. 
Table 6

Soil structural quality based on water aggregate stability of a sandy loam and a silt loam soil under cereal monoculture (CM) and permanent pasture (PP).

\begin{tabular}{|c|c|c|c|c|c|c|c|c|c|c|}
\hline \multirow[t]{3}{*}{ Soils } & \multirow[t]{3}{*}{ Land use } & \multicolumn{7}{|c|}{ Visual assessment } & \multicolumn{2}{|c|}{ Wet sieving } \\
\hline & & \multicolumn{3}{|c|}{ Sampling moisture } & \multirow[t]{2}{*}{ Class } & \multicolumn{2}{|c|}{ Air-dried } & \multirow[t]{2}{*}{ Class } & \multirow[t]{2}{*}{$\operatorname{MWD}(\mathrm{mm})$} & \multirow[t]{2}{*}{ Class } \\
\hline & & $\theta\left(\mathrm{cm}^{3} \mathrm{~cm}^{-3}\right)$ & $5 \mathrm{~min}$ & $10 \mathrm{~min}$ & & $5 \mathrm{~min}$ & $10 \mathrm{~min}$ & & & \\
\hline \multirow[t]{2}{*}{ Sandy loam } & $\mathrm{CM}$ & 0.21 & $\begin{array}{l}1.9 \\
(0.1)\end{array}$ & $\begin{array}{l}1.5 \mathrm{~b} \\
(0.4)\end{array}$ & Moderately good & $\begin{array}{l}1.2 \\
(0.5)\end{array}$ & $\begin{array}{l}0.9 \mathrm{~b} \\
(0.5)\end{array}$ & Moderate bad & $\begin{array}{l}0.46 \mathrm{~b} \\
(0.1)\end{array}$ & Poor \\
\hline & $\mathrm{PP}$ & 0.17 & $\begin{array}{l}2.0 \\
(0.0)\end{array}$ & $\begin{array}{l}2.0 \mathrm{a} \\
(0.0)\end{array}$ & Good & $\begin{array}{l}2.0 \\
(0.0)\end{array}$ & $\begin{array}{l}2.0 \mathrm{a} \\
(0.1)\end{array}$ & Good & $\begin{array}{l}0.83 \mathrm{a} \\
(0.1)\end{array}$ & Good \\
\hline \multirow[t]{2}{*}{ Silt loam } & $\mathrm{CM}$ & 0.28 & $\begin{array}{l}1.7 \\
(0.3)\end{array}$ & $\begin{array}{l}1.5 \mathrm{~b} \\
(0.3)\end{array}$ & Moderately good & $\begin{array}{l}0.6 \\
(0.5)\end{array}$ & $\begin{array}{l}0.2 \mathrm{~b} \\
(0.2)\end{array}$ & Poor & $\begin{array}{l}0.40 \mathrm{~b} \\
(0.1)\end{array}$ & Poor \\
\hline & PP & 0.30 & $\begin{array}{l}2.0 \\
(0.0)\end{array}$ & $\begin{array}{l}2.0 \mathrm{a} \\
(0.0)\end{array}$ & Good & $\begin{array}{l}1.9 \\
(0.1)\end{array}$ & $\begin{array}{l}1.9 \mathrm{a} \\
(0.1)\end{array}$ & Good & $\begin{array}{l}1.0 \mathrm{a} \\
(0.0)\end{array}$ & Good \\
\hline
\end{tabular}

$\theta=$ volumetric soil water content at sampling.

Standard deviation for each soil indicator is given in parenthesis $( \pm)$.

Values in a column followed by the same letter are not significantly different at $P>0.05$.

$-10 \mathrm{cmH}_{2} \mathrm{O}\left(R^{2}=0.56\right)$ in the silt loam soil. Although significant relationships $(P<0.05)$ were found between the morphological scores and the soil physical and hydraulic properties, $R^{2}$ values remained low in our study and could only explain $<56 \%$ of the variation of the VSA, VESS and visual type of aggregate index scores of both the sandy loam and the silt loam soils.

On the other hand, with regards to the visual score of the aggregate stability, strongest relationships were found with the soil physical and hydraulic properties. In the silt loam soil, there were significant relationships between the visual score of aggregate stability and SOC $\left(R^{2}=0.89\right)$, MacP $\left(R^{2}=0.71\right)$, MicP $\left(R^{2}=0.95\right)$, TPV $\left(R^{2}=0.49\right), \mathrm{AC}\left(R^{2}=0.80\right)$, PAWC $\left(R^{2}=0.91\right)$ and MWD $\left(R^{2}=0.94\right)$. For the sandy loam soil relationships were evidenced with AC $\left(R^{2}=0.65\right)$ and $\operatorname{MWD}\left(R^{2}=0.59\right)$, and with $K_{(\mathrm{h})}$ at different pressure heads $\left(0.33<R^{2}<0.43\right)$.

\section{Discussion}

The visual examinations used in our study, reflect the different conditions related to the complexity of the soil structure: (i) VESS method in the silt loam soil was able to reveal the compaction present in the PP plot under permanent grazing; (ii) the visual type of aggregates index indicated a poorer condition in the sandy soil, where a more angular type of aggregates was found; (iii) the visual aggregate stability showed the effect of tillage on aggregate stability of CM. This is in accordance with Mueller et al. (2013) who showed the feasibility and reliability of visual examination methods such as VSA and VESS, for giving scores and classes characterizing the soil potential for cropping.

When numerical quantification of these visual examinations was used as a factor in the estimation of soil physical and hydraulic properties, simple relationships were found. These relationships suggest that for our soils a visual quality is associated with at least one quantitative quality. In the silt loam soil, the visual examinations were most related to properties such as SOC, PAWC, MWD and porosity, whereas in the sandy loam soil they were most associated with water flow properties (Table 7).

In the silt loam soil, the soil structural quality of the different plots was equally classifies by SOC (as an individual indicator) and water stability tests. Whereas a dissimilar classification was given

Table 7

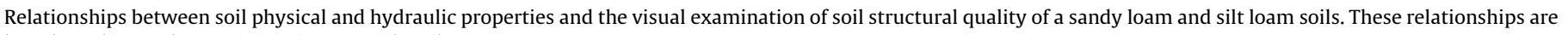
based on the 12 observation points at each soil.

\begin{tabular}{|c|c|c|c|c|c|}
\hline \multicolumn{3}{|c|}{ Sandy loam soil } & \multicolumn{3}{|c|}{ Silt loam soil } \\
\hline Equation & $R^{2}$ & $\alpha$ & Equation & $R^{2}$ & $\alpha$ \\
\hline $\mathrm{BD}=-0.0131(\mathrm{VSA})+1.7266$ & 0.53 & 0.00 & $\mathrm{SOC}=-0.232(\mathrm{VSA})+9.53$ & 0.45 & 0.01 \\
\hline $\log K_{\mathrm{s}}(\mathrm{TI})=-0.50(\mathrm{VESS})+0.3239$ & 0.43 & 0.02 & $\mathrm{MacP}=0.01$ (VSA) -0.281 & 0.35 & 0.04 \\
\hline $\log K_{(\mathrm{h}=-1 \mathrm{~cm})}=-0.476(\mathrm{VESS})+0.18$ & 0.41 & 0.02 & $\mathrm{MicP}=-0.023(\mathrm{VSA})+1.165$ & 0.45 & 0.01 \\
\hline $\log K_{(\mathrm{h}=-3 \mathrm{~cm})}=-0.4301(\mathrm{VESS})-0.0724$ & 0.38 & 0.03 & $\mathrm{AC}=0.018(\mathrm{VSA})-0.48$ & 0.42 & 0.02 \\
\hline $\log K_{(\mathrm{h}=-10 \mathrm{~cm})}=-0.3673(\mathrm{VESS})-0.5927$ & 0.37 & 0.03 & $\mathrm{PAWC}=-0.02(\mathrm{VSA})+0.877$ & 0.43 & 0.02 \\
\hline $\log K_{\mathrm{s}}(\mathrm{TI})=0.2721(\mathrm{Tagg})-1.9808$ & 0.40 & 0.02 & $\mathrm{MWD}=-0.079(\mathrm{VSA})+3.304$ & 0.50 & 0.01 \\
\hline $\log K_{(\mathrm{h}=-1 \mathrm{~cm})}=-0.26(\mathrm{Tagg})-0.448$ & 0.39 & 0.02 & $\mathrm{SOC}=1.364(\mathrm{VESS})-2.265$ & 0.51 & 0.00 \\
\hline $\log K_{(\mathrm{h}=-3 \mathrm{~cm})}=-0.234(\mathrm{Tagg})-0.6468$ & 0.36 & 0.03 & $\mathrm{MicP}=0.128(\mathrm{VESS})+0.03$ & 0.47 & 0.01 \\
\hline $\log K_{\mathrm{s}}(\mathrm{TI})=-0.4258(\mathrm{VSt})-0.5018$ & 0.33 & 0.03 & $\mathrm{TPV}=0.051(\mathrm{VESS})+0.366$ & 0.47 & 0.00 \\
\hline $\log K_{(\mathrm{h}=-1 \mathrm{~cm})}=-0.434(\mathrm{VSt})-0.553$ & 0.37 & 0.03 & PAWC $=0.10($ VESS $)-0.077$ & 0.35 & 0.03 \\
\hline $\log K_{(\mathrm{h}=-3 \mathrm{~cm})}=-0.3992(\mathrm{VSt})-0.7314$ & 0.38 & 0.03 & $\mathrm{MWD}=0.422(\mathrm{VESS})-0.572$ & 0.47 & 0.01 \\
\hline $\log K_{(\mathrm{h}=-6 \mathrm{~cm})}=-0.394(\mathrm{VSt})-0.92$ & 0.41 & 0.02 & $\log K_{(\mathrm{h}=-3 \mathrm{~cm})}=-0.659($ Tagg $)-0.146$ & 0.35 & 0.03 \\
\hline $\log K_{(\mathrm{h}=-10 \mathrm{~cm})}=-0.3747(\mathrm{VSt})-1.106$ & 0.43 & 0.02 & $\log K_{(\mathrm{h}=-6 \mathrm{~cm})}=-0.602(\mathrm{Tagg})-0.459$ & 0.41 & 0.02 \\
\hline$A C=-0.0294(V S t)+0.1823$ & 0.65 & 0.00 & $\log K_{(\mathrm{h}=-10 \mathrm{~cm})}=-0.434(\mathrm{Tagg})-1.144$ & 0.56 & 0.00 \\
\hline \multirow[t]{7}{*}{$\mathrm{MWD}=0.2633(\mathrm{VSt})+0.2641$} & 0.59 & 0.00 & $\mathrm{SOC}=1.061(\mathrm{VSt})+0.739$ & 0.89 & 0.00 \\
\hline & & & $\mathrm{MacP}=-0.047(\mathrm{VSt})+0.107$ & 0.71 & 0.00 \\
\hline & & & $\mathrm{MicP}=0.107(\mathrm{VSt})+0.304$ & 0.95 & 0.00 \\
\hline & & & $\mathrm{TPV}=0.030(\mathrm{VSt})+0.49$ & 0.49 & 0.01 \\
\hline & & & $\mathrm{AC}=-0.0775(\mathrm{VSt})+0.187$ & 0.80 & 0.00 \\
\hline & & & PAWC $=0.0939(V S t)+0.129$ & 0.91 & 0.00 \\
\hline & & & $\mathrm{MWD}=0.345(\mathrm{VSt})+0.3372$ & 0.94 & 0.00 \\
\hline
\end{tabular}

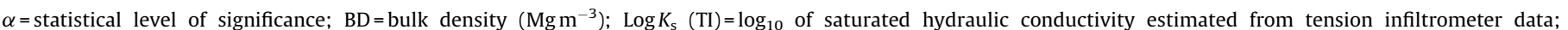

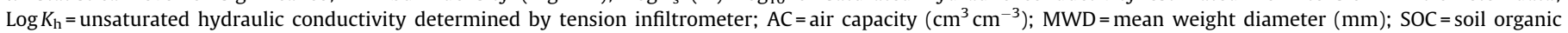

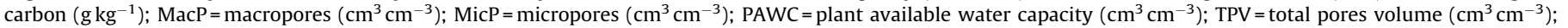

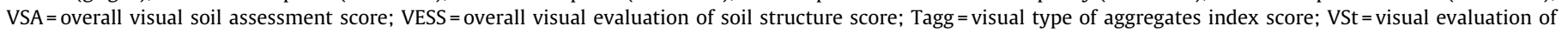
aggregate stability score (air-dried aggregates). 
by SOC when compare to VSA, VESS, MacP, MicP and AC. In this soil, the permanent presence of cattle on PP results in a constant addition of manure, which increases SOC content. But also in soil compaction from the cattle trampling that counteracted the possible positive effect of SOC on soil structure. This opposite trend has been also mentioned by Newell-Price et al. (2013). Our results suggest that caution should be taken when using SOC as a sole soil quality indicator in some conditions, as is often suggested when deriving minimal data sets for soil quality evaluation (e.g. Shukla et al., 2006). On the other hand, morphological evaluations could give an immediate idea about properties that are time-consuming in laboratory measurements, such as PAWC, MicP and MacP. Subsequently, some inferences could be drawn for plant growth and agricultural practices.

The higher aggregate stability found in soils under $\mathrm{PP}(P<0.01$, Table 6) can be attributed to the presence of a higher density of roots (visually evaluated) and a higher SOC content, which can keep mineral particles together against destructive forces (Bronick and Lal, 2005).

Although several authors have mentioned relationships between the overall score of VSA and VESS with soil properties under different conditions (Shepherd, 2000, 2009; Mueller et al., 2009, 2013; Guimaraes et al., 2013), some disadvantages of these methods have been mentioned. For instance, Newell-Price et al. (2013) have appointed some weaknesses of using VSA in grassland systems, where distinct contrasting layers can be found, ensuring that the scores of the poorest layer within the topsoil could provide a better indication of physical soil quality than a weighted average score for the whole topsoil layer. This could be considered in the case of the sandy loam soil, where unfavourable soil structure (angular aggregates) was only described in the sub layer present in some of the blocks of soil.

The relationships between the visual type of aggregates index and the soil physical and hydraulic properties showed that the water flow was facilitated when a higher amount of rounded aggregates was present in both the sandy loam and the silt loam soils. Sandy soils are expected to have a higher hydraulic conductivity when no limitations of flow are present based on the visual type of aggregate index. Generally, well-structured soils with rounded aggregates tend to drain more easily than soils with a poor structure or angular aggregates (Hu et al., 2009). According to Alvarez et al. (2012) the lower roughness of the aggregates results from the pressure exerted by farming and mutual friction.

In this study, as was mentioned before, the unfavourable soil structure under the silt loam soil was not in correspondence with the visual type of aggregates index. The interaction between the root system and the higher SOC in this plot could have had a higher effect on the shape of the aggregates.

Morphological characteristics evaluated in the field have been referred to as important tools in the classification of the soil $K_{\mathrm{s}}$ values, therefore it can be considered as factors to be incorporated into hydraulic models (Ingelmo et al., 2011). In this study, we showed the existence of single relationships between soil hydraulic conductivity measurements using TI and different soil properties. This confirms that the quantification of soil morphology can be incorporated as soil structural information into the hydraulic models. However, limitations are presented when there is an absence of a proper means for quantifying soil morphology (Lin et al., 1999a). Classification criteria have to be well defined before quantifying morphological characteristics; hence the VSA and VESS protocols, visual type of aggregates index and visual aggregate stability are possible alternatives. Note that the relations between morphological test scores and hydraulic conductivity were dominantly present in the sandy soil, which suggests a more uniform pore system (homogeneous pore size distribution) in the sandy loam soil compared to the silt loam soil.
Moreover, $K_{\mathrm{s}}$ measured with LP was not correlated with any of the morphological evaluations, most probably because of the high variability in $K_{\mathrm{s}}$. Differences in $K_{\mathrm{s}}$ using LP, and $K_{(\mathrm{h})}$ using TI demonstrate the variation in values according to the method used (Verbist et al., 2013), but also the importance of the sizes of the pores participating in the water flow. Our results are supported by those of Reynolds et al. (2000) and Verbist et al. (2013) who found that TI values are significantly lower than any other method. $K_{\mathrm{s}}$ values estimated from the TI measurements showed lower variability (57\%) than LP values (125\%). When determining $K_{\mathrm{s}}$ from TI measurements, only water flow in pores smaller than $3 \mathrm{~mm}$ in diameter is considered, whereas in case of LP all pores of the soil medium in the core samples contribute to water flow, including the larger pores due to burrows made by earthworms, which typically show a high variability (Hu et al., 2009). Macroporosity is an integral part of soil structure, which is deficiently reflected by single soil physical and hydraulic properties. Therefore, morphological indices of soil structure are crucial in characterizing the hydraulic behaviour in the MacP flow region (Lin et al., 1999b).

Caution is required in using these relationships, which were developed under the evaluated conditions, to other soil conditions because of the site-specific relationships found and the limited data set used. However, we must emphasize that those could be used as support for the validity of the use of the visual examination for evaluating soil structural quality. Evaluation of root density and type of soil organic matter present in the soils should be included in further studies to better understand the relationships found.

\section{Conclusions}

Moderate to good relationships were found between visual examinations and values of soil physical and hydraulic properties. This supports their use as reliable semi-quantitative methods to assess soil structural quality. The VSA, the VESS, the visual type of aggregates index and the visual assessment of aggregate stability could be considered as encouraging visual estimators of soil physical properties. Because of the differences in the relationships demonstrated in this study for soils under contrasting texture and land use, further studies in correlating morphological evaluations and quantitative soil physical properties could be done in other soil textures and management systems. Finally, two aspects should be emphasized: (i) relationships between visual examinations and hydrophysical properties are promising; therefore morphological properties could be worth considering for predicting hydrophysical soil properties; and (ii) from the dissimilarities in terms of soil quality found between the visual examination of soil structure and the amount of SOC, SOC should be used cautiously as a sole indicator for soil structural quality as has been proposed in literature, because SOC per se is not always well related to the soil structural quality classes.

\section{Acknowledgements}

This research was supported in part by the Consejo de Desarrollo Científico y Humanístico $(\mathrm{CDCH})$ of the Universidad Central de Venezuela and with the cooperation of the Department of Soil Management, Ghent University, Belgium. Letiane Helwig Penning was a student fellow of the 'Science without borders' program from $\mathrm{CNPq}$ - National Counsel of Technological and Scientific Development of Brazil. The authors are grateful to Maarten Volckaert of the Department of Soil Management, Ghent University for his technical assistance. The authors are also thankful to the anonymous referees for their helpful comments and suggestions. 


\section{References}

Alvarez, M.F., Osterrieth, M.L., del Rio, J.L., 2012. Changes on aggregates morphology and roughness induced by different uses of Typical Argiudolls, Buenos Aires province, Argentina. Soil and Tillage Research 119, 38-49.

Ball, B.C., Batey, T., Munkholm, L.J., 2007. Field assessment of soil structural quality a development of the Peerlkamp test. Soil Use and Management 23, 329-337.

Ball, B.C., Munkholm, L.J., Batey, T., 2013. Applications of visual soil evaluation. Soil and Tillage Research 127, 1-2.

Batey, T., 2000. Soil profile description and evaluation. In: Smith, K.A., Mullins, C.E. (Eds.), Soil and Environmental Analysis: Physical Methods. 2nd ed. Marcel Dekker Inc., New York.

Batey, T., 2009. Soil compaction and soil management - a review. Soil Use and Management 25, 335-345.

Batey, T., McKenzie, D.C., 2006. Soil compaction: identification directly in the field. Soil Use and Management 22, 414.

Beste, A., 1999. An Applicable Field Method for the Evaluation of Some Ecologically Significant Soil-function-Parameters in Science and Agricultural Consulting Practice. International Soil Conservation Organisation Conference West Lafayette, Indiana, USA.

Boizard, H., Batey, T., McKenzie, D.C., Richard, G., Roger-Estrade, J., Ball, B.C., Bradley, I., Cattle, S., Hasinger, G., Munkholm, L.J., Nievergelt, J., Peigné, J., Shepherd, G., 2005. Field Meeting "Visual soil structure assessment" Detailed Report. INRA, France. Available at:http://iworx5.webxtra.net.

Bronick, C.J., Lal, R., 2005. Soil structure and management: a review. Geoderma 124, 3-22.

Cornelis, W.M., Khlosi, M., Hartmann, R., Van Meirvenne, M., De Vos, B., 2005. Comparison of unimodal analytical expressions for the soil-water retention curve. Soil Science Society of America Journal 69, 1902-1911.

Fagroud, M., Van Meirvenne, M., 2002. Accounting for soil spatial autocorrelation in the design of experimental trials. Soil Science Society of America Journal 66, $1134-1142$.

FAO, 2006. Guidelines for Soil Description. Available at: ftp://ftp.fao.org/agl/agll/ docs/guidel_soil_descr.pdf (accessed 12.2012).

Field, D.J., McKenzie, D.C., Koppi, A.J., 1997. Development of an improved Vertisol stability test for SOILpak. Australian Journal of Soil Research 35, 843-852.

Garbout, A., Munkholm, L.J., Hansen, S.B., 2013. Tillage effects on topsoil structural quality assessed using X-ray CT, soil cores and visual soil evaluation. Soil and Tillage Research 128, 104-109.

Gee, G.W., Or, D., 2002. Particle-size analysis. In: Dane, J.H., Topp, G.C. (Eds.), Methods of Soil Analysis. 3rd ed. Part. 4: Physical Methods. Soil Sci. Soc. Am., Madison, pp. 255-293.

Greenland, D.J., 1981. Soil-management and soil degradation. Journal of Soil Science 32, 301.

Guimaraes, R.M.L., Ball, B.C., Tormena, C.A., Balarezo Giarola, N.F., da Silva, A.P., 2013. Relating visual evaluation of soil structure to other physical properties in soils of contrasting texture and management. Soil and Tillage Research 127, 92-99.

Guimaraes, R.M.L., Ball, B.C., Tormena, C.A., 2011. Improvements in the visual evaluation of soil structure. Soil Use and Management 27, 395-403.

Hu, W., Shao, M., Wang, Q., Fan, J., Horton, R., 2009. Temporal changes of soil hydraulic properties under different land uses. Geoderma 149, 355-366.

Ingelmo, F., Jose Molina, M., Miguel de Paz, J., Visconti, F., 2011. Soil saturated hydraulic conductivity assessment from expert evaluation of field characteristics using an ordered logistic regression model. Soil and Tillage Research 115, 27-38.

Karlen, D.L., Ditzler, C.A., Andrews, S.S., 2003. Soil quality: why and how? Geoderma $114,145-156$.

Kemper, W.D., Rosenau, R.C., 1986. Aggregate stability and size distribution. In: Klute, A. (Ed.), Methods of Soil Analysis. Part 1, Physical and Mineralogical Methods. Agronomy Monograph N ${ }^{\circ}$. 2nd ed. American Society of Agronomy, Inc., Madison, WI.

Klute, A., Dirksen, C., 1986. Hydraulic conductivity and diffusivity: laboratory methods. In: Klute, A. (Ed.), Methods of Soil Analysis. Part 1. Agronomy Monograph $\mathrm{N}^{\circ}$ 9. 2nd. ed. ASA and SSSA, Madison, WI, pp. 687-734.

Lal, R., Shukla, M.K., 2004. Principles of Soil Physics. Marcel Dekker, New York, ISBN: 0-8247-5324-0, pp. 716.
Lin, H.S., McInnes, K.J., Wilding, L.P., Hallmark, C.T., 1999a. Effects of soil morphology on hydraulic properties: I. Quantification of soil morphology. Soil Science Society of America Journal 63, 948-954.

Lin, H.S., McInnes, K.J., Wilding, L.P., Hallmark, C.T., 1999b. Effects of soil morphology on hydraulic properties: II. Hydraulic pedotransfer functions. Soil Science Society of America Journal 63, 955-961.

Logsdon, S.D., Jaynes, D.B., 1993. Methodology for determining hydraulic conductivity with tension infiltrometers. Soil Science Society of America Journal 57, 1426-1431.

Mueller, L., Kay, B.D., Hu, C., Li, Y., Schindler, U., Behrendt, A., Shepherd, T.G., Ball, B.C., 2009. Visual assessment of soil structure: evaluation of methodologies on sites in Canada, China and Germany. Part I: Comparing visual methods and linking them with soil physical data and grain yield of cereals. Soil and Tillage Research 103, 178-187.

Mueller, L., Shepherd, G., Schindler, U., Ball, B.C., Munkholm, L.J., Hennings, V. Smolentseva, E., Rukhovic, O., Lukin, S., Hu, C., 2013. Evaluation of soil structure in the framework of an overall soil quality rating. Soil and Tillage Research 127 , 74-84.

Newell-Price, J.P., Whittingham, M.J., Chambers, B.J., Peel, S., 2013. Visual soil evaluation in relation to measured soil physical properties in a survey of grassland soil compaction in England and Wales. Soil and Tillage Research 127, 65-73.

NRCS (Natural Resources Conservation Services), 2003. Saturated Hydraulic Conductivity: Water Movement Concepts and Class History. United States Department of Agriculture. Available at: http://soils.usda.gov/technical/technotes/ note6.html (Verified August 8, 2013).

Peerlkamp, P.K., 1959. A visual method of soil structure evaluation. Meded. v. d. Landbouwhogeschool en Opzoekingsstations van de Staat te Gent XXIV (24) 216-221.

Pierce, F.J., Larson, W.E., Dowdy, R.H., Graham, W.A.P., 1983. Productivity of soils assessing long-term changes due to erosion. Journal of Soil and Water Conservation 38, 39-44.

Reynolds, W.D., Bowman, B.T., Brunke, R.R., Drury, C.F., Tan, C.S., 2000. Comparison of tension infiltrometer, pressure infiltrometer, and soil core estimates of saturated hydraulic conductivity. Soil Science Society of America Journal 64, 478-484.

Reynolds, W.D., Drury, C.F., Tan, C.S., Fox, C.A., Yang, X.M., 2009. Use of indicators and pore volume-function characteristics to quantify soil physical quality. Geoderma 152, 252-263.

Reynolds, W.D., Drury, C.F., Yang, X.M., Fox, C.A., Tan, C.S., Zhang, T.Q., 2007. Land management effects on the near-surface physical quality of a clay loam soil. Soil and Tillage Research 96, 316-330.

Reynolds, W.D., Elrick, D.E., 1991. Determination of hydraulic conductivity using a tension infiltrometer. Soil Science Society of America Journal 55, 633-639.

Saey, T., Simpson, D., Vitharana, U.W.A., Vermeersch, H., Vermang, J., Meirvenne, M.V., 2008. Reconstructing the paleotopography beneath the loess cover with the aid of an electromagnetic induction sensor. Catena 74, 58-64.

Schultz, B.B., 1985. Levene's test for relative variation. Systematic Biology 34 (4) 449-456.

Shepherd, T.G., 2000. Visual Soil Assessment. Volume 1. Field Guide for Cropping and Pastoral Grazing on Flat to Rolling Country. Horizons.mw \& Landcare Research, Palmerston North, pp. 84.

Shepherd, T.G., 2009. Visual Soil Assessment. Volume 1. Field Guide for Pastoral Grazing and Cropping on Flat to Rolling Country, 2nd ed. Horizons Regional Council, Palmerston North, pp. 119.

Shukla, M.K., Lal, R., Ebinger, M., 2006. Determining soil quality indicators by factor analysis. Soil and Tillage Research 87, 194-204.

Verbist, K.M.J., Cornelis, W.M., Torfs, S., Gabriels, D., 2013. Comparing methods to determine hydraulic conductivities on stony soils. Soil Science Society of America Journal 77, 25-42.

Walkley, A., Black, I.A., 1934. An examination of the Degtjareff method for determining organic carbon in soils: effect of variations in digestion conditions and of inorganic soil constituents. Soil Science 63, 251-263.

Wooding, R.A., 1968. Steady infiltration from a shallow circular pond. Water Resources Research 4, 1259. 